\title{
The effect of liquid losses in trainings during competition period on some biochemical values of u18 male judokas ( age 15-17)
}

\author{
Nuri Muhammet Çelik ${ }^{1}$, Malik Beyleroğlu², Mehmet Soyal ${ }^{3}$, Vahit Çiriş ${ }^{1}$ \\ ${ }^{1}$ Physical Education and Sports Teaching, Institute of Educational Sciences, Sakarya University, Sakarya, Turkey \\ ${ }^{2}$ Faculty of Sport Sciences, Sakarya University, Sakarya, Turkey \\ ${ }^{3}$ School of Physical Education and Sports, Istanbul Esenyurt University, Istanbul, Turkey
}

\begin{abstract}
Purpose:

The purpose of this study is to investigate the effect of liquid losses occurring in training sessions during the competition period on some biochemical values of the male Judokas competing in the U18 category.

Material: $\quad$ The values of the 17 male athletes, who were included in the national team at least once, were checked in our study which compares the values of athletes before the competition and immediately after the competition. Urine Density, Urine $\mathrm{pH}, \mathrm{BUN}$, Creatine and Potassium values from the biochemistry values were measured besides the age, height and weight of the athletes participating in the study.

Results: $\quad$ As a result of the measurements made; it was found that the kg pre-test averages of the participant athletes were $67,82 \pm 17,87$, post-test averages were $64,88 \pm 16,89$, Urine Density pre-test averages were $1.017,94 \pm 7,08$, posttest averages were $1.025 \pm 8,48$, Urine $\mathrm{pH}$ pre-test averages were $6,15 \pm 0,70$, post-test averages were 5,82 $\pm 0,50$, BUN pre-test averages were $15,65 \pm 3,14$, post-test averages were $24,35 \pm 3,60$, Creatine pre-test averages were $0,48 \pm 0,20$, post-test averages were $0,93 \pm 0,41$, K Potassium pre-test averages were $4,16 \pm 0,35$, post-test averages were $4,95 \pm 0,64$. As a result of the statistical analysis, although there was no significant difference in urine $\mathrm{pH}$ pretest and post-test values, statistically significant difference was found between pre-test and post-test values in other selected parameters $(p<0,05)$.

Conclusions: As a result; it is thought that in our country in which the adjustment of the weight class is made unconsciously and unplanned, this will lead to the health problems of the athletes in many ways, especially in the later ages. Particularly in the professional sense, the health problems, which athletes who enter weight competitions and who enter at least 10 international competitions in the Olympic sense for the Judo branch a year can experience in the later ages as a result of such exhaustion, should be well considered. The the significant differences in studies in the literature and in our work also indicate that acute and rapid dehydration causes athletes to be harmed in terms of health and leads to the loss of performance. The result of our study is that the athletes should be prompted for weight control in a planned way to prevent the adjusting weight by acute and excessive dehydration.

Keywords: Judo, Dehydration, weight loss, Olympic cycle, Biochemical Values.
\end{abstract}

\section{Introduction}

In today's world of technology, sport is defined as a form of life and educational tool. The application of the sport in different age categories and performance levels by the individuals living in the society shows that it is an important component of life.

Among the factors that make individuals interested in sports are the earnings of successful athletes, being at the forefront in the society, the recognition by the whole world and the media [1]. Particularly with team sports, the right orientation and increased interest in individual sports have made sports more popular and appealing to the more people . Judo, one of the most important parts of individual sports in the world, is considered to be one of the premise branches that young people are interested in.

In a sport that requires a high level of skill, such as Judo, the development of analytical functions and the ability to quickly perceive and act in the ever-changing conditions of the competition are described as the characteristics that the athletes dealing with this sport need to improve. In addition, the decisions that athletes will make in the event of a complex game are thought to depend on their perception of external stimuli. The level of quick thinking and interpretation plays an important role in preventing the opponent from making a successful tactical behavior or succeeding in his own tactic $[2,3]$.

In sports such as Judo, the level of training, perception ability, experience as well as body weight are seen as

\footnotetext{
(C) Nuri Muhammet Çelik, Malik Beyleroğlu,

Mehmet Soyal, Vahit Çiriş, 2017

doi:10.15561/20755279.2017.0508
}

important factors for the success of the athletes. Athletes who want to be successful want to lose weight in order to compete in a lower weight class. Judokas frequently use training methods that include severe sweating, sweating in the sauna, heavy workouts and heavy exercises in a hot environment, with a severe or full hunger diet that they apply very seriously in order to be successful in falling to a lower weight class. The implementation of these intensive methods in short time by the athletes is causing health and performance problems. The use of weight loss and dehydration methods in such a short period of time by the athletes cause risks for both their health and their success $[4,5,6]$. While dehydration is known as fluid loss, it also means the losses of electrolytes in the clinical sense. In the early stages of fluid loss, sodium and chloride ions are lost along with the water in the body. If the water and the electrolytes of which level falls in the body are not replaced, the volume of intravenous fluid decreases. Blood circulation slows down. The slowing of blood circulation results in decreased oxygenation of tissues leading to adverse effects on performance [7, 8].

The way in which athletes lower their body weight is often seen as acute weight loss. It is not possible for the athletes in the developmental age to compete in a higher weight class due to their developing body structure. It is more common to lower the acute body weight in the athletes who see it as a disadvantage. Acute weight loss leads to a reduction in the plasma volume and blood volume of the athletes. In submaximal exercises, there are many changes physiologically and biochemically affecting the athlete in a negative way. In particular, 
electrolyte imbalance, reduced volume of fluid filtered in the kidney, increased urine density, and reduced glycogen storage in the liver, resulting in poor performance [9]. In particular, the fact that the methods used in the precompetition process do not adequately replace the loss of fluid in the body does not only reduce the performance, but also causes serious health problems and even deaths in the athletes [10].

Acute body weight decrease is important in determining how it affects the body of athletes and their biochemistry values, resolving this frequently encountered problem and increasing the knowledge of coaches and athletes about this issue, raising more efficient athletes and, most importantly, raising healthy and successful athletes. This study is planned to determine the extent to which damage to the athletes and biochemical changes will be caused by the methods of fast body weight loss applied in today's sports events and weight sports like Judo.

\section{Material and methods}

\section{Participants}

Research group of the study consists of 17 male judoka volunteers who participated in the Turkish Judo National Team at least once, live in Konya province and will compete in the Turkish U18 Championship and whose average age was $16.29 \pm 1.49$ years and length averages was $174.35 \pm 9.42$.

Collection of Data

The training period and dermographic measurements of this study were carried out in the Konya Metropolitan Municipality Judo Training Center Hall and biochemical analyzes were carried out in Selçuk University Medical Faculty Biochemistry Laboratory.

The age of the athletes participating in the study was determined by taking into account the identity information. The lengths of the subjects were measured with the F. Bosh FB-200 length measurement device. Subjects' initial body weight measurements were measured in the morning, while the athletes were hungry and only had shorts on them. The second weight measures of the athletes were 21 days after the first measurement and in the morning of the competition and they were measured during the official weighing and also with the shorts which are the minimum clothes.

Urine and blood were collected from all the athletes who participated in the study for the determination of biochemistry values, which are Urine Density, Urine PH, BUN, Creatine and Potassium values, 21 days before the competition. Biochemical changes were also investigated by taking urine and blood for biochemistry measurements 21-23 days after the first measurement from all the athletes participating in the study.

\section{Training Period}

Athletes participating in the training were included in the training program of the competition period under the supervision of Konya Büyükşehir Belediyesi Spor Kulübü coaches. The athletes who were preparing to participate in the Turkish Championship in the annual activity program participated in the competition after the measurements. The training program used was as follows; strenght exercises were applied as maximum strength, continuity of the strength and quick strength exervise, and they were programmed to be general and special strength. In addition to the strength training, durability and technical tactic trainings particular to Juda were also carried out.

Statistical analyses

Analysis of the data was done in SPSS Statistics 17.0 software package. The measurement results were given as mean (X) and standard deviation (SD). Paired t-test was applied to dependent groups to compare height weight and biochemical data before and after training. Significance level was accepted as $\mathrm{p}<0,05$.

\section{Results}

Measurements of height and weight of the athletes participating in the study, as well as measurements related to the Biochemical Values before and after the 21-day Competition Training period were summarized in the following tables. When Table 1 is examined; the mean age of the athletes was $16.29 \pm 1.49$ years. When looking at the length measurements; length average was $174.35 \pm$ $9.42 \mathrm{~cm}$ and the shortest athlete was $156 \mathrm{~cm}$ and the tallest athlete was $185 \mathrm{~cm}$.

When Table 2 is examined; kg pre-test average was $67,82 \pm 17,87$ and post-test average was $64,88 \pm 16,89$. From the other values, Urine Density pre-test average was $6,15 \pm 0,70$, post-test average was $5,82 \pm 0,50$, Bun pre-test average was $15,65 \pm 3,14$, post-test average was $24,35 \pm 3,60$, Creatine pre-test average was $0,48 \pm 0,20$, post-test average was $0,93 \pm 0,41$, Potassium pre-test average was 4,16 $\pm 0,35$, post-test average was 4,95 $\pm 0,64$. Although there was no statistically significant difference in urine $\mathrm{pH}$ pre-test and post-test values as a result of the statistical analysis, statistically significant difference was observed between pre-test and post-test values of other selected parameters $(p<0,05)$.

Table 1. Demographic Characteristics of Judiciaries Participating in the Study (Mean \pm SD)

\begin{tabular}{llllll}
\hline Variables & $\mathbf{n}$ & $\mathbf{X}$ & SD & Min & Max \\
\hline Age (years) & 17 & 16,2941 & 1,49016 & 14 & 19 \\
Length $(\mathrm{cm})$ & 17 & 174,3529 & 9,42696 & 156 & 185 \\
\hline
\end{tabular}


Table 2. Values of Judokas 21 Days Before and During Competition (Mean \pm SD)

\begin{tabular}{|c|c|c|c|c|c|c|}
\hline Variables & Measurements & $\mathbf{n}$ & $x$ & SD & $\mathbf{t}$ & $\mathbf{p}$ \\
\hline \multirow{2}{*}{$\begin{array}{l}\text { Body weight } \\
\text { ( Kg) }\end{array}$} & Pre-test & 17 & 67,82 & 17,87 & \multirow{2}{*}{8,977} & \multirow{2}{*}{, $000 *$} \\
\hline & Post-test & 17 & 64,88 & 16,89 & & \\
\hline \multirow{2}{*}{$\begin{array}{l}\text { Urine Density } \\
\text { (mg/dl) }\end{array}$} & Pre-test & 17 & $1.017,94$ & 7,08 & \multirow{2}{*}{$-2,742$} & \multirow{2}{*}{, $014^{*}$} \\
\hline & Post-test & 17 & $1.025,00$ & 8,48 & & \\
\hline \multirow{3}{*}{ Urine PH } & Pre-test & 17 & 6,15 & 0,70 & \multirow{3}{*}{2,021} & \multirow{3}{*}{,060 } \\
\hline & & & & & & \\
\hline & Post-test & 17 & 5,82 & 0,50 & & \\
\hline \multirow{2}{*}{$\begin{array}{l}\text { BUN } \\
\text { (mg/dl) }\end{array}$} & Pre-test & 17 & 15,65 & 3,14 & \multirow{2}{*}{$-10,776$} & \multirow{2}{*}{, $000 *$} \\
\hline & Post-test & 17 & 24,35 & 3,60 & & \\
\hline \multirow{2}{*}{$\begin{array}{l}\text { Creatine } \\
\text { (mg/dl) }\end{array}$} & Pre-test & 17 & 0,48 & 0,20 & \multirow{2}{*}{$-4,800$} & \multirow{2}{*}{, $000 *$} \\
\hline & Post-test & 17 & 0,93 & 0,41 & & \\
\hline \multirow{2}{*}{$\begin{array}{l}\text { Potassium } \\
(\mathrm{mg} / \mathrm{dl})\end{array}$} & Pre-test & 17 & 4,16 & 0,35 & \multirow{2}{*}{$-6,513$} & \multirow{2}{*}{, $000 *$} \\
\hline & Post-test & 17 & 4,95 & 0,64 & & \\
\hline
\end{tabular}

${ }^{*} p<0,05$

\section{Discussion}

In this study conducted to investigate the effect of liquid loss caused by the training of male Judo athletes competing in the U18 category during the competition period on pre-test and post-test results, body weight $(67,82 \pm 17,87 \mathrm{~kg}, 64,88 \pm 16,89 \mathrm{~kg}$, respectively), Urine Density $(1.017,94 \pm 7,08 \mathrm{mg} / \mathrm{dl}, \quad 1.025,00 \pm 8,48 \mathrm{mg} /$ $\mathrm{dl}$, respectively), Urine $\mathrm{PH}(6,15 \pm 0,70,5,82 \pm 0,50$, respectively), Bun $(15,65 \pm 3,14 \mathrm{mg} / \mathrm{dl}, 24,35 \pm 3,60 \mathrm{mg} /$ $\mathrm{dl}$, respectively), Creatine $(0,48 \pm 0,20 \mathrm{mg} / \mathrm{dl}, 0,93 \pm 0,41$ $\mathrm{mg} / \mathrm{dl}$, respectively), Potassium (4,16 $\pm 0,35 \mathrm{mg} / \mathrm{dl}, 4,95$ $\pm 0,64 \mathrm{mg} / \mathrm{dl}$, respectively) were detected.

In the literature review, no study that examined the effect of liquid loss on judokas on the biochemical values we have studied was found. This raises the importance of our study and limits our discussion.

One of the most important factors in sports is to have the proper weight. In some sports, athletes try to gain weight, while in a weight class branches, athletes try to control weight or lose weight [11]. The total calories consumed by people vary depending on the size of the body, gender, and sport. The most effective way to lose weight is to reduce calorie intake and increase the burned calories [12]. While most of the athletes compete in their own weight class, some athletes compete in the weight classes below their weight. Weight loss and regain are common in these athletes. Typically, this turn is frequent, fast, and wide. The main purpose of the popular use of loss by the athlete is to overcome their opponents in the same weight class who have not lost weight and to provide a power advantage [13, 14]. Fast weight loss due to extreme fluid loss for 1-2 days of athletes will affect their performances negatively [15]. Weight loss through excessive fluid loss does not only disrupt muscle performance, it also prevents sweating and affects the regulation of body temperature during performance [16].

In the study conducted, pre-test and post-test body weights of male judokas were $67,82 \pm 17,87 \mathrm{~kg}, 64,88 \pm$ $16,89 \mathrm{~kg}$ respectively. A statistically significant difference was found in the body weight pre-test and post-test parameters in the 21-day competition preparation period $(\mathrm{p}<0,05)$.

In the study conducted by Rico et al. (2015), the body weights were determined as $73.58 \pm 14.99 \mathrm{~kg}, 70.38 \pm$ $14.84 \mathrm{~kg}$ in the study of pre-competition dehydration effects in martial sports [17]. In another study, Evans et al. (2011) reported that the average weight of the judokas was $70,13 \pm 7,5 \mathrm{~kg}$ and that weight loss was $5 \%$ by various methods of weight loss in martial sports [18]. In another study, Alpay et al. (2015) compared 69 wrestlers who lost weight and who did not lose weight and they found that the body weight average in the athletes who lost weight was $78.98 \pm 15.87 \mathrm{~kg}$ and body weight loss was $3.66 \pm 1.41 \mathrm{~kg}$ [19]. In another study conducted by 
Degoutte et al. (2006) on 10 jukodas about the effects of the nutritional restrictions of judokas on physiological, hormonal, biochemical and performance, body weight pre-test and post-test values were detected as $75.9 \pm 3.1$ $\mathrm{kg}$ and $72.1 \pm 1.4 \mathrm{~kg}$, respectively, and a statistically significant difference was determined [20]. When the literature is examined, it is seen that body weight values of the studies performed are in parallel with our study.

Urinary density is expressed as the weight in $\mathrm{mg}$ of $1 \mathrm{ml}$ urine. Urinary density varies from 1015 to 1025 in adult humans, but it can be as low as 1002 or as high as 1040 , depending on the amount of water intake. If the urinary density is higher than the densities of distilled water, that is, 1000 , this is mainly due to $\mathrm{Na}^{+}$and $\mathrm{K}^{+}$from the organic and inorganic substances it contains. If the last two digits of urine density are multiplied by 2,237 , known as the Häser coefficient, the amount of solid matter in 1 liter of urine can be found in grams.

The amount of total solids in a 24-hour urine of a healthy adult person weighing $75 \mathrm{~kg}$ is $60 \mathrm{~g}$. It is defined as isostenuria when urine density is constantly around 1010. Isostenuria occurs during the terminal period of chronic glomerulonephritis. It is defined as hypertermia when urine density is continuously higher than 1030 . Hyperthermia is seen in diabetes mellitus and dehydration [21]. During dehydration, urine density and osmolarity increase. In a severe dehydration the urine density goes above 1030 [22].

The pre-test and post-test urine densities of male judokas were 1.017,94 \pm 7,08mg / $\mathrm{dl}$ and 1,025,00 $\pm 8,48$ $\mathrm{mg} / \mathrm{dl}$, respectively. There was a statistically significant difference in the urine density pre-test and post-test values in the 21-day preparation period $(\mathrm{p}<0,05)$.

Akyüz (2009) determined the urine density pre-test and final test values as 1020,75 $\pm 7,39 \mathrm{ml} / \mathrm{dl}, 1019,13 \pm$ $4,65 \mathrm{ml} / \mathrm{dl}$ in the study of the effect of rapid weight loss on physical, physiological and biochemical parameters in elite wrestlers and did not find a statistically significant difference [21]. This result is not statistically different from the values in our study, which is thought to be caused by preferences in the weight loss method.

Urine PH level of an adult person who takes nourishment at a normal level is around 5-6. Urine $\mathrm{pH}$ reference range may vary between 4.8-7.4. Measurement of $\mathrm{PH}$ is necessary to monitor the effects of kidney infections, stones, and certain medications [23,24]. Protein-rich nutrition, sleep, metabolic acidosis, respiratory acidosis, diarrhea and dehydration are factors that cause acidic urination. Causes such as bicarbonate intake, unbalanced nutrition with fruits and vegetables, urinary infections, metabolic alkalosis, respiratory alkalosis, renal disease (renaltubulerasidosis) may also cause basic urine formation $[23,24,25,26]$. PH changes due to fluid loss are the most severe and most frequent changes in $\mathrm{pH}$, which are described as hypochloremic alkalosis and hyperchloremic acidosis [21].

In our study, urinary $\mathrm{pH}$ values were detected as pre-test and post-test $(6,15 \pm 0,70$ and 5,82 $\pm 0,50$, respectively). As a result of the statistical evaluation, it was determined that there was no significant difference between the pre- and post-test $\mathrm{PH}$ parameters.

Akyüz (2009) found that urine PH values were $6.8 \pm$ 1.04 and $6.70 \pm 0.78$ as the pre-test and post-test values, respectively, in the study of the effects of rapid weight loss on physical, physiological and biochemical parameters in elite wrestlers, and there was no statistically significant difference between them [21]. This result is parallel to our study.

The intention of urea synthesis is making the ammonia, which arises as the excess, non-toxic. For this purpose, $1 \mathrm{~mol}$ of free ammonia, $1 \mathrm{mmol}$ of bicarbonate and $1 \mathrm{~mol}$ of aspartic acid the amino group nitrogen in liver cells are combined with a multi-step cycle, and urea is synthesized. In anormal human beings weighing $70 \mathrm{~kg}$, urea is produced up to $0.5 \mathrm{~mol}$ (30 gr). Urea formation can rise up to 3 times in protein-rich diet. [27] Urea is a non-protein nitrogenous substance [28]. Urea is an ammonium-synthesized substance that is produced by the liver as a result of protein metabolism. It is usually a requested test for renal problems. However, changes may also be seen in cases where renal function is not present because the urea is synthesized in the liver and when there is tubular rezabsorption. Excessive protein intake, infusion of aminoacids, gastrointestinal system bleeds, and the use of corticosteroids and tetracycline drugs are also factors that increase the level of urea. Blood urea levels may also be low in situations such as protein deficiency, acute and chronic severe liver disease caused by any reason. It is a product of protein metabolism and is thrown out through the kidneys with the urine. It is frequently is measured as the blood urea nitrogen (BUN) [29]. In normal individuals, about $40 \%$ to $60 \%$ of the filtered urine is thrown out with the urine. Urea is the most abundant waste product that should be thrown out by the kidneys.

In our study, BUN parameter pre-test and post-test results of the judokas were found to be $(15,65 \pm 3,14 \mathrm{mg} /$ $\mathrm{dl}, 24,35 \pm 3,60 \mathrm{mg} / \mathrm{dl}$, respectively). It was determined that there was a statistical difference between BUN values of judokas.

Alpay et al. (2015) compared the 69 international wrestlers who lost/did not lose weight in the study and found that BUN value was $16.44 \pm 3.44 \mathrm{ml} / \mathrm{dl}$ in athletes who did not lose weight and $14.31 \pm 3.63$ in the athletes who lost weight [19]. In another study, Akyüz (2009) found a statistically significant difference in BUN parameter pretest and post-test values for the effect of rapid weight loss on physical, physiological and biochemical parameters of elite wrestlers [21]. In a similar study, Degoutte et al. (2006) reported that in the study of 10 jukodas, they found statistically significant differences in BUN pre-test and post-test results in studying the physiological, hormonal, biochemical effects of jukodas' nutrition restrictions on performance [20]. Our work is parallel to these results.

Blood urea and blood urea nitrogen (BUN) and creatinine levels are increased (prerenal insufficiency) as glomerular filtration rate decreases during dehydration. Both urea and urea nitrogen (BUN) are affected by factors such as tissue breakdown and tubular reabsorption, as 
well as the amount of protein taken in the diet.

Creatinine is filtered from the glomeruli, is not reabsorbed, is secreted in small quantities from the tubules. Creatine kinase is a very valuable for measuring the rate of glomerular filtration since creatine is completely excreted from the kidneys [21]. Creatinine values are a good parameter for kidney function. Creatinine is proportional to body muscle mass. For this reason, normal creatinine levels in young children are lower than in older children and adults. Children with chronic malnutrition may have normal serum creatinine levels, even if renal function is impaired, due to the lack of muscle mass. Creatinine measurements can be found to be high even if renal function is impaired by other chromogenic substances such as bilirubin and ketone bodies [22].

In our study, creatinine pre-test and post-test values were determined as $0,48 \pm 0,20 \mathrm{mg} / \mathrm{dl}, 0,93 \pm 0,41$ $\mathrm{mg} / \mathrm{dl}$, respectively. It was concluded that there was a statistically significant difference between pretreatment and posttreatment values of creatinine. In a similar study, Akyüz (2009) found a statistically significant difference in creatine value pre-test and post-test values in the study of the effect of rapid weight loss on physical, physiological and biochemical parameters in elite wrestlers [21]. This result is statistically close to our study.

In the study conducted, potassium pre-test and posttest values were found to be $4,16 \pm 0,35 \mathrm{mg} / \mathrm{dl}$ and 4,95 $\pm 0,64 \mathrm{mg} / \mathrm{dl}$, respectively, and there was a statistically significant difference between them.

Costill et al. [31] and Sejersted et al. [32] observed a significant increase in the amount of blood potassium $(\mathrm{K})$ due to muscle potassium $(\mathrm{K})$ exchange in the event of body fluid loss based on training. Kenefik et al. [33], Ebert et al. [34] and Rivera et al. [35] observed an increase in blood potassium $(\mathrm{K})$ levels in blood parameter results after exercise and heat acclimatization. Noakes et al. [36] studied 2135 athletes in their study and examined blood Hematocrit values there. Some of these subjects were dehydrated and fluid restriction was applied, and some of them received liquid supplement. As a result, a significant increase in the amount of blood potassium in the dehydrated group was observed while there was no significant increase in the amount of blood potassium in group that received liquid supplement. When we look at the literature we see that the results are parallel to our study.

\section{Conclusion}

As a result; it is thought that in our country in which the adjustment of the weight class is made unconsciously and unplanned, this will lead to the health problems of the athletes in many ways, especially in the later ages. Particularly in the professional sense, the health problems, which athletes who enter weight competitions and who enter at least 10 international competitions in the Olympic sense for the Judo branch a year can experience in the later ages as a result of such exhaustion, should be well considered. The significant differences in studies in the literature and in our work also indicate that acute and rapid dehydration causes athletes to be harmed in terms of health and leads to the loss of performance. The result of our study is that the athletes should be prompted for weight control in a planned way to prevent the adjusting weight by acute and excessive dehydration.

\section{Funding/support}

No financial or grant support was received for this work.

\section{Conflicts of interest}

The authors have no conflicts of interest relevant to this study.

\section{References}

1. Erdem S, Şahin M. Sports Ethics and Problems.7th International Congress on Sport Sciences. 27-29th October 2002. Evrensel Publishing Istanbul; 2002. P.157- 55.

2. Mauro CG de Alencar C, Landau L, Janotta Drigo A. Judokas' Hand Grip Strength Study, Accordıng To Age, Weight Class And Championship Performance. Annals of the 5th International Judo Federation World Research Symposium. September 12th, Brazil, Rio de Janeiro: 2007. P. 100-105.

3. Demiral Ş. An Investigation of the Effect of Judo Educational Games on the Development of Motor Skills in 7-12 Age Group Children Doing Judo (Male-Female). [PhD thesis]. Istanbul: Marmara University; 2010.

4. Başaran M. Wrestling Teaching and Training Principles. (4th Print), Youth Sports Academy Publications. Manisa; 1989.

5. Ransone J, Hughest B. Body Weight Fluctuation In Collegate Wrestlers Implications Of The National Collegiate Athletic Association Weight Certification Program. Journal of Athletic Training, 2004; 39 (2): 162-169.

6. Ersoy G. Nutrition for Doers of Exercise and Sports. (3. Print). Ankara: Nobel Publishing House; 2004.

7. Paker S. Special Nutrients Used by Athletes. ODTÜ Physical
Education and Sports Sciences Health and Guidance Center. 1993-1994 Academic Year Seminars Series. Ankara; 1994.

8. Maglishco EW. :Swimming Even Faster.California: Mayfield Pub.; 1993.

9. Yıldırım Z. Health Sciences Institute Determination of physical and motoric profiles of elite female wrestlers. [PhD thesis]. İstanbul: Department of Physical Education and Sport Sciences; 2007.

10.Hawley J, Burke L. Peak Performance Training and Nutritional Strategies for Sport, Part 3. İstanbul; 1998.

11.Aydos L. Experimental Investigation of Effects of Short-term Weight Loss Before Competition on Strength and Durability in Wrestlers, [PhD thesis]. Istanbul: Marmara University Institute of Health Sciences; 1991.

12.Kalyon TA. Sportsman Health and Sports Injuries, 4th print. Ankara: Gata Publishing House; 1997.

13.Oopık V, Paasuke M, Sikko T, Timpmann S, Medijainen L. Ereline J, Smirnova T, Gapejeva E. Effect Of Rapid Weight Loss On 81 Metabolism And Isokinetic Performance Capacity. A Case Study Of Two Well Trained Wrestlers. The Journal of Sports Medicine and Physical Fitness, 1996;36(2):127-131. 
14.Timpmann S, Öpik V, Pääsuke M, Medijainen L, Ereline J. Acute Effects Of Self-Selected Regimen Of Rapid Body Mass Loss İn Combat Sports athletes. Journal of Sports Science and Medicine, 2008; 7: 210-217.

15.K1lıç M. Wrestlers in the Stars category (15-16 age group) Performance Effect of Short-Term Liquid Loss, [PhD thesis]. Konya: Selçuk University Health Sciences Institute, Physical Education and Sports Department; 1998.

16.Sten SN, Brownell KD. Patterns Of Weight Loss And Regain In Wrestlers: Has The Tradition Changed. Medicine and Science in Sports and Exercise, 1990;22(6):762-768.

17.Calvo Rico B,Garcia Garcia JM, Monteiro LF, Rioja Collado $\mathrm{N}$. Kinematic indicators in combat sports athletes in a precompetitive dehydrated status. Archives Of Budoscience Of Martial Arts And Extreme Sports, 2015;11:181-188.

18.Langan-Evans C, Close GL, Morton JP. Gaining weight in Martial Arts. Journal of Power and Healing, 2011;33 (6): 25-39.

19.Alpay CB, Ersöz Y, Karagöz Ş, Oskouei MM. PreCompetition Weight Loss in Elite Wrestlers, Comparison of Body Composition and Some Mineral Levels. International Journal of Science Culture and Sport (IntJSCS), 2015; 3(4): 338-348.

20.Degoutte F, Jouanel P, Begue RJ, Colombier M, Lac G, Pequignot JM, Filaire E. Food restriction, performance, biochemical, psychological, andendocrine changes in judo athletes. International journal of sports medicine, 2006; 27(01): 9-18.

21.Akyüz M. The Effect of Fast Weight Loss on Physical, Physiological and Biochemical Parameters in Elite Wrestlers, [PhD thesis]. Ankara: Gazi University, Institute of Health Sciences Physical Education and Sports; 2009.

22.Aydin A. Dehydration and Intravenous Fluid Therapy. Cerrahpaşa Medical Faculty Continuing Medical Education Activities Summer Diarrhea-Food Poisoning Symposium 8-9 June 1998. Istanbul; 1998. P. 45-61.

23.Brunzel NA. Fundamentals Of Urine And Body Fluid
Analysis, Edition 2. Elsevier, Philadelphia; 2004.

24.Wilson LA. Urinalysis. Nursing Standard. 2005; 19:51-54.

25.Sözmen E, Akçay Y, Sezer E: Urine Analysis and Clinical Use. İzmir: Meta Printing; 2004.

26.Benejam R, Narayana AS. Urinalysis. The Physician's Responsibility. Am Fam Physician. 1985; 31:103-11.

27.Kalaycıoğlu L, Serpek B, Nizamlığlu M, Başpınar N, Tiftik AM. Biochemistry, Ankara: Nobel Publishing Distribution Ltd. Co; 2000. (In Turkish)

28.Y1lmaz B. Hormones and Reproduction Physiology, 1st Print, Ankara: Feryal Printing Press; 2000.

29.Altun B. Kidney Function Tests. [Internet] 2009 Apr 17 [updated 2010 Jan 1; cited 2017 Apr 8]. Available from: http://www.steteskop.net/ozetler-pa-print_pdf-pid-428.html

30.Günay M, Cicioğlu İ, Kara E. Metabolic and Heat Adaptation in Exercise, Ankara: Gazi Bookstore; 2006.

31.Costill DL, Cote R, Fink W. Muscle Water And Electrolytes Following Varied Levels Of DehydrationIn Man. J Appl Physiol.2006;40:6-11.

32.Sejersted OM, Sjøgaard G. Dynamics And Consequences Of Potessium Shifts In Skeletal Muscle And Hearth During Exercise. Physiol Rev. 2000;80:1411-1481.

33.Kenefick RW, Hazzard MP. Thirst Sensations and AVP Responses at Rest and During Exercise-Cold Exposure. Med. Sci. Sports. Exe. 2004;36(9)1528-34.

34.Ebert TR, Martin DT. Influence of Hydration Status on Thermo regulation and Cycling Hill Climbing. Med Sci Sports Exerc. 2007;39(2):323-9.

35.Rivera AM, Rowland TW. Exercise Tolerance in a Hot and Humid Climatized Girls and Women. Int. J. Sports Med. 2007;27(12):943-950.

36.Noakes TD, Sharwood K. Three Independent Biological Mechanisms Cause Exercise-Associated Hyponatremia: Evidence From 2135 Weighed Competitive Athletic Performances. Proc. Natl. Acad. Sci. U.S.A. 2005.102(51):18550-18555.

Information about the authors:

Nuri Muhammet Çelik; http://orcid.org/0000-0001-6403-6262; nmcelik42@hotmail.com; Physical Education and Sports Teaching, Institute of Educational Sciences, Sakarya University; Esentepe Campus 54187 Serdivan, Sakarya, Turkey.

Malik Beyleroğlu; http://orcid.org/0000-0002-2223-0064; mbeyler@sakarya.edu.tr; Faculty of Sport Sciences, Sakarya University; Esentepe Campus 54187 Serdivan, Sakarya, Turkey.

Mehmet Soyal; http://orcid.org/0000-0001-6528-0275; mehmetsoyal3838@hotmail.com; School of Physical Education and Sports Sakarya University; Sakarya University Esentepe Campus 54187 Serdivan, Sakarya, Turkey.

Vahit Çiriş; http://orcid.org/0000-0002-3087-0942; vahitciris@gmail.com; Physical Education and Sports Teaching, Institute of Educational Sciences, Sakarya University; Sakarya University Esentepe Campus 54187 Serdivan, Sakarya, Turkey.

Cite this article as: Nuri Muhammet Çelik, Malik Beyleroğlu, Mehmet Soyal, Vahit Çiriş. The effect of liquid losses in trainings during competition period on some biochemical values of u18 male judokas ( age 15-17) Physical education of students, 2017;21(5):249-254. doi:10.15561/20755279.2017.0508

The electronic version of this article is the complete one and can be found online at: http://www.sportedu.org.ua/index.php/PES/issue/archive

This is an Open Access article distributed under the terms of the Creative Commons Attribution License, which permits unrestricted use, distribution, and reproduction in any medium, provided the original work is properly cited (http://creativecommons.org/licenses/by/4.0/deed.en).

Received: 12.06.2017

Accepted: 25.07.2017; Published: 09.09.2017 